\title{
Analysis of the technological parameters of 3D printing on the strength properties of finished MABS and PET products
}

\author{
Aleksander Gabryśs ${ }^{1}$, Tomasz Dembiczak², Robert Kruzel ${ }^{3}$
}

\begin{abstract}
:
The aim of the study was to understand the influence of the technological parameters of 3D printing in FDM (Fused Deposition Modeling) technology on the mechanical properties of MABS and PET material. Samples for static tensile tests were printed in accordance with PN-EN ISO 527: 1998. Plastics. Determination of mechanical properties under static stretching. The print parameters for each sample, regardless of the type of filament used, were the same. Only the filling parameter was modified by changing the density $(20,40$, $80 \%$ ) and the filling pattern (line pattern and honeycomb). Laboratory tests were carried out with the use of a universal testing machine. PET showed higher tensile strength values than MABS at different sample filling densities.
\end{abstract}

\section{KEYWORDS:}

3D printing; optimization of 3D printing parameters; static tensile test; MABS; PET

\section{Introduction}

Due to the dynamic development of the industry, 3D printing, the layered production of physical objects based on three-dimensional computer models prepared with the use of CAD software, has become more and more popular [1].

3D printing allows the significant shortening of the time it takes to make a prototype, or the actual product itself, in comparison to classic deleterious manufacturing methods. Their use contributes to lowering the price of implementing a new product and giving designers and engineers the opportunity to test a large number of variants of the final product in a short period of time $[2,3]$. Currently, on the market the prices of basic printers are not that high and are available for anyone buy. Such printers are mostly used by plastic plants where they first make a prototype of the designed detail or part before implementing it into serial production [4].

3D printing technology is also used in conducting engineering research of materials produced using a 3D printer.

During 3D printing, there are many parameters that affect the quality, speed and durability of the printed model. To properly control the printing process, it is important to know how a given parameter affects the properties of the model. The most important parameters include: number of coats, printing speed, printing temperature, layer height and filling density [5].

\footnotetext{
1 Jan Dlugosz University in Czestochowa, Alumn

2 Jan Dlugosz University in Czestochowa, al. Armii Krajowej 13/15, 42-200 Częstochowa, e-mail: t.dembiczak@ujd.edu.pl, orcid id: 0000-0003-2751-3749

${ }^{3}$ Czestochowa University of Technology, Faculty of Civil Engineering, ul. Akademicka 3, 42-218 Częstochowa, e-mail: robert.kruzel@pcz.pl, orcid id: 0000-0002-8534-7286
} 


\section{Materials and methods}

Two types of MABS and PET filaments were used for the tests. These are products of the Polish company 3D Kreator. Table 1 presents the manufacturer's information on the filaments used during the tests.

\section{Table 1}

Characteristics of 3d Kreator filaments

\begin{tabular}{|l|l|}
\hline Filaments & $\begin{array}{l}\text { Characteristics of materials } \\
\text { MABS is a very strong impact-resistant filament. It is ideal for printing permanent 3D } \\
\text { prints. Due to its physical properties, MABS is widely used in industry. The material } \\
\text { from which this filament is made is very light and durable. This makes MABS especially } \\
\text { suitable for tools, toys and all kinds of equipment. Printing at a temperature slightly } \\
\text { above the average temperature for the } 3 \mathrm{D} \text { MABS filament makes the printed elements } \\
\text { even more durable. Printing temperature } 220 \div 270^{\circ} \mathrm{C} \text {, melting temperature } 245^{\circ} \mathrm{C} \pm 10^{\circ} \mathrm{C} .\end{array}$ \\
\hline $\begin{array}{l}\text { PET is an odorless, very durable filament with high transparency. These features make } \\
\text { it flexible and does not shrink after remelting. Thanks to this, the printed models retain } \\
\text { their original sizes. PET is an excellent material that combines the advantages of both } \\
\text { PLA and ABS. Printing temperature } 195 \div 220^{\circ} \mathrm{C} \text {. }\end{array}$ \\
\hline
\end{tabular}

Preparation of test samples was divided into two stages. In the first stage, a 3D model of the sample intended for a static tensile test was made in accordance with the PN-EN ISO 527-3: 1998 standard. Plastics. Determination of mechanical properties under static stretching [6] The geometry of a flat sample is shown in (Fig. 1), while the spatial model of the sample made in the SolidWorks 2016 [7] program is presented in (Fig. 2).

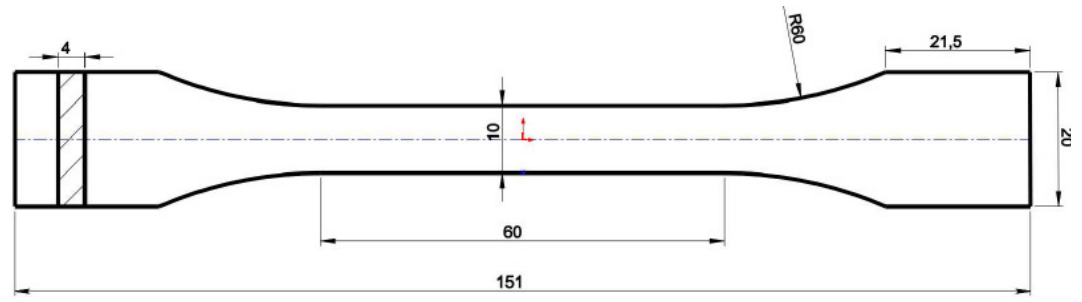

Fig. 1. Sample for tensile tests drawn in the SolidWorks 2016 program in accordance with PN-EN ISO 527: 1998

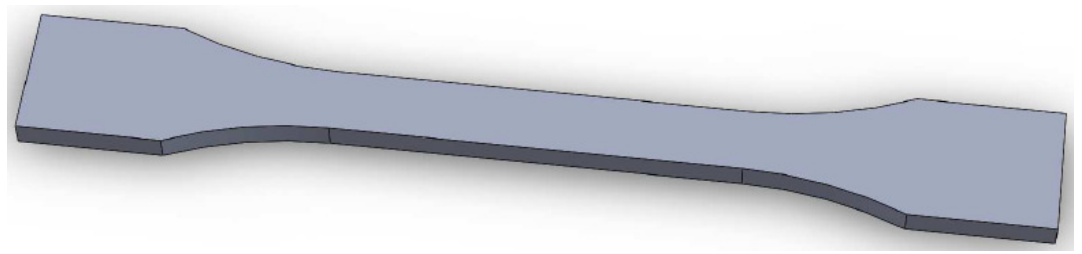

Fig. 2. Tensile sample space model drawn in SolidWorks 2016

In the second stage, the technological parameters of printing were introduced and the G-Code was generated using the Cura slicer on April 15, 3. (Fig. 3). The printing process in FDM (Fused Deposition Modeling) technology was carried out with the use of a Dexer 3D printer. 
The printer is equipped with a table heated to a temperature of $100^{\circ} \mathrm{C}$ with a printing area of $200 \times 200 \times 200 \mathrm{~mm}$. Equipped with two printing heads with a diameter of $0.4 \mathrm{~mm}$, the diameter of the filaments used was $1.75 \mathrm{~mm}$.

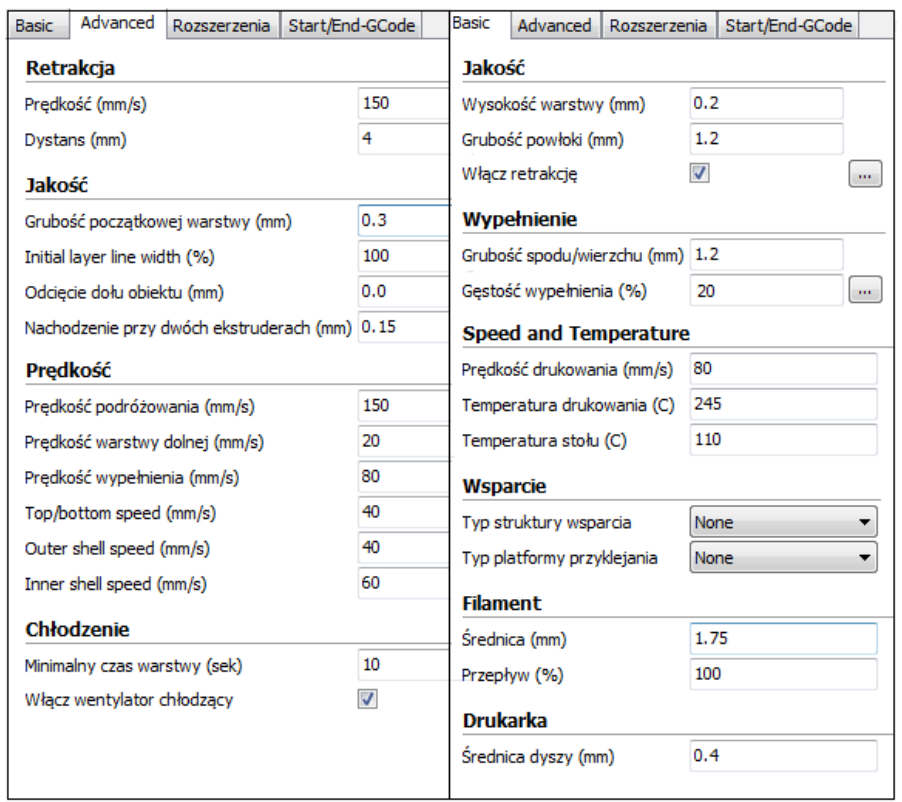

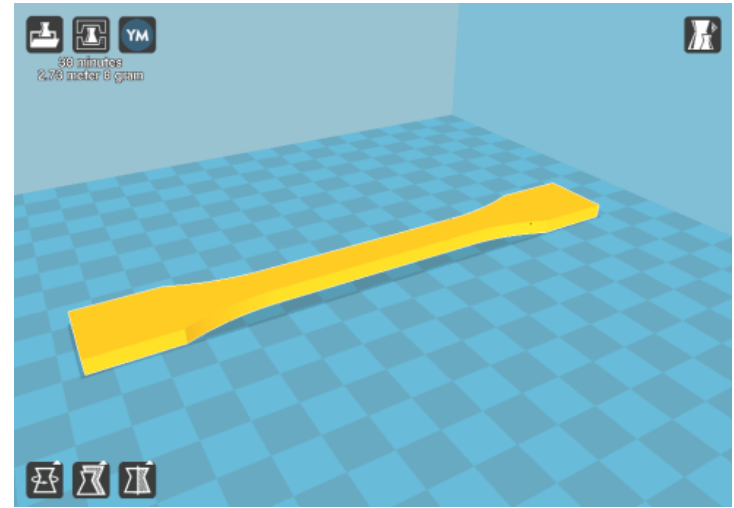

Fig. 3. An example of the technological parameters for a sample with a filling density of $20 \%$ honeycomb

The samples were printed in FDM technology from two different MABS and PET filaments. The print parameters for each sample, regardless of the type of filament used, were the same. Only the filling parameter was changed by changing the density $(20,40,80 \%)$ and the filling pattern (line pattern and honeycomb). Figure 4 shows examples of samples with a filling density of 20,40 and $80 \%$.

In order to find out the influence of the dependence of the technological parameters on the mechanical properties of MABS and PET filaments, a static tensile test was performed. A testing machine was used for the static strength test. An example of a sample made of MABS filament with a designated measuring base and a marked scale is shown in (Fig. 5). 


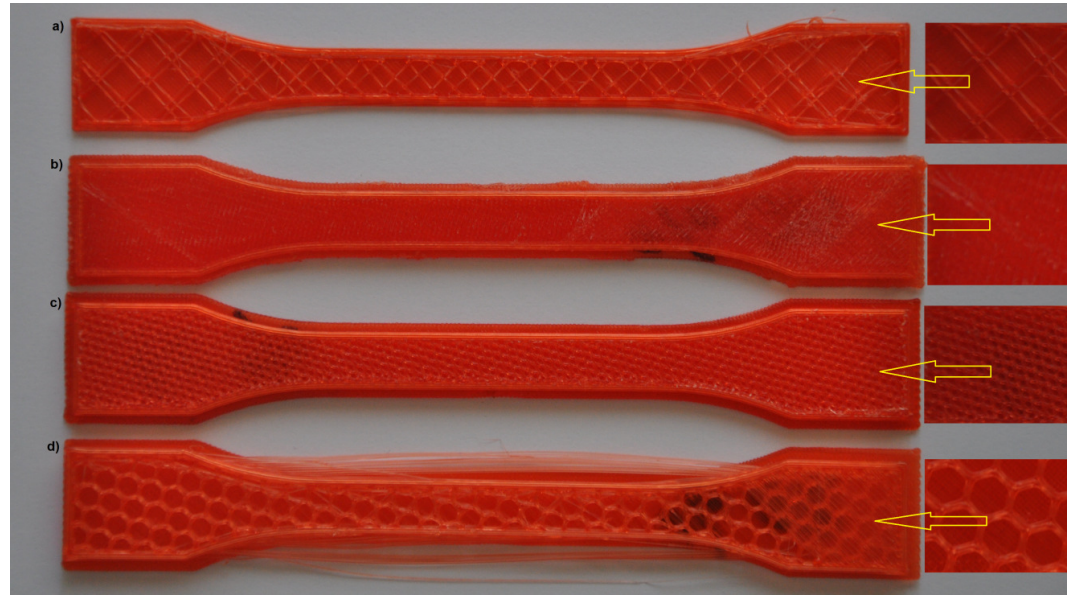

Fig. 4. MABS filament samples: a) with a linear pattern and $20 \%$ fill density; b-d) honeycomb formula with fill density: b) $80 \%$; c) $40 \%$; d) $20 \%$

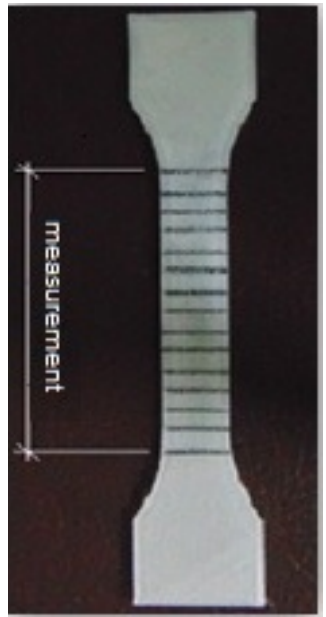

Fig. 5. Prepared test sample with a measuring base of $50 \mathrm{~mm}$

\section{Results and discussion}

The conducted research is aimed at understanding the influence of the dependence of technological parameters on the mechanical properties of MABS and PET filaments. Exemplary tensile strength diagrams with $80 \%$ fill density and linear and honeycomb patterns are shown in (Figs. 6 and 7).

Based on the analysis of the tensile strength test results, it was found that the samples made of PET filament are characterized by a higher strength index than the samples made with MABS. With the filling pattern of the honeycomb sample and the filling density of $80 \%$ for the sample made of PET, the tensile strength was $\mathrm{Rm}=43.4 \mathrm{MPa}$, while with the linear formula, the tensile strength was $\mathrm{Rm}=37.8 \mathrm{MPa}$. The samples made of MABS with a filling density of $80 \%$ with a honeycomb filling pattern were characterized by a tensile strength of $\mathrm{Rm}=33.5 \mathrm{MPa}$, while with a linear filling, the tensile strength was $\mathrm{Rm}=22.5 \mathrm{MPa}$. Table 2 shows the results of the MABS and PET samples with the honeycomb and linear filling pattern for 20 and $40 \%$ filling density. 


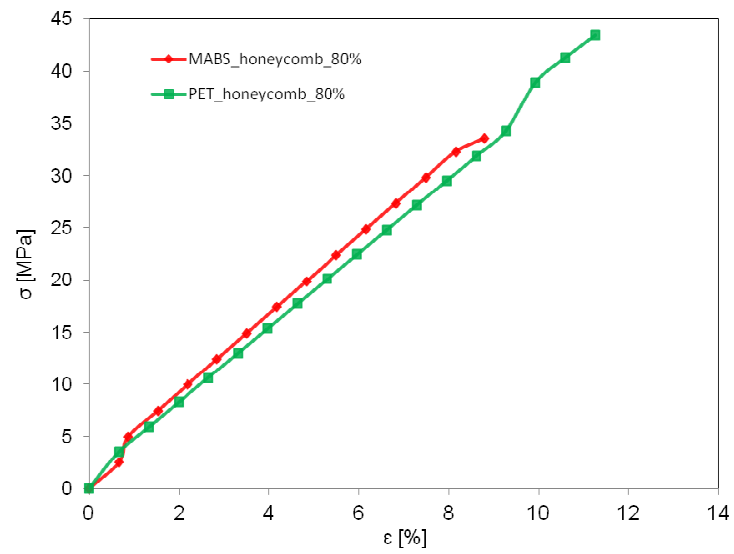

Fig. 6. Comparison of the tensile strength of the MABS filament with PET with the honeycomb filling pattern and a density of $80 \%$ filling

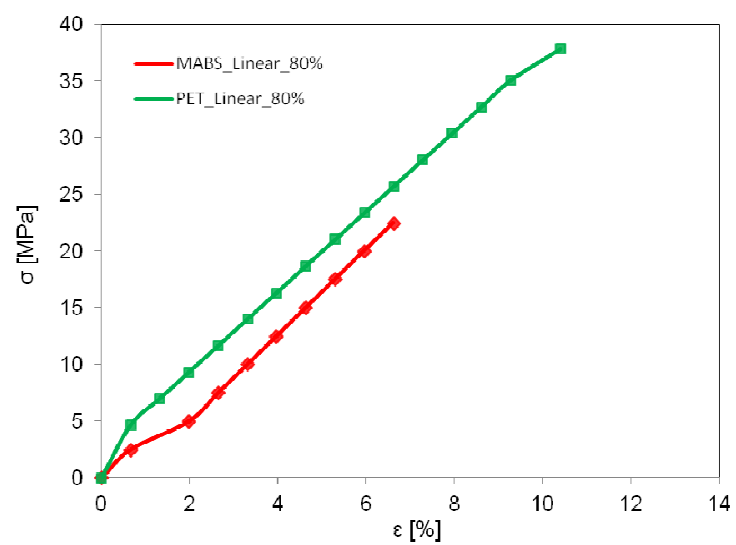

Fig. 7. Comparison of the tensile strength of the MABS filament with PET with a linear fill pattern and $80 \%$ fill density

Table 2

Tensile strength test results for MABS and PET filaments

\begin{tabular}{|l|l|l|l|l|l|}
\hline Filaments & Fill pattern & $\rho[\%]$ & $\varepsilon[\%]$ & $\sigma[\mathrm{MPa}]$ & $\mathrm{A}_{\mathrm{p}}[\%]$ \\
\hline \multirow{2}{*}{ MABS } & \multirow{2}{*}{ honeycomb } & 20 & 4.8 & 15.8 & 10.7 \\
\cline { 3 - 6 } & & 40 & 6.4 & 21.5 & 17.7 \\
\hline \multirow{2}{*}{ PET } & \multirow{2}{*}{ honeycomb } & 20 & & & \\
\hline & & 40 & 8.5 & 26.5 & 15.7 \\
\hline \multirow{2}{*}{ MABS } & \multirow{2}{*}{ linear } & 20 & 5.5 & 33.5 & 17.7 \\
\hline & & 40 & 6.4 & 12.4 & 11.7 \\
\hline \multirow{2}{*}{ PET } & \multirow{2}{*}{ linear } & 20 & & 13.7 & 10.0 \\
\cline { 3 - 6 } & & 40 & 6.6 & 22.0 & 14.0 \\
\hline
\end{tabular}

where: $\rho$ - material filling density, $\varepsilon$ - strain during stretching, $\sigma$ - stress during stretching, $A_{p}$ - percentage elongation of the sample 
Based on the analysis of the tensile strength test results, it was found that the honeycomb filling pattern improves the tensile strength with the increase of the filling density. It was also found that samples made of PET material are characterized by higher tear strength than samples made of MABS material.

\section{Conclusions}

The quality of a physically made model using 3D printing technology depends, among other things, on the layer height, coating thickness, filling density, printing speed, printing temperature, table temperature and the type of filament.

Manufacturers provide the optimal printing parameters for the purchased filaments in order to obtain high-quality products. No information is available on the mechanical properties. Therefore, laboratory tests are necessary to understand the mechanical properties. The known strength indicators of various types of filaments will allow for the appropriate selection of construction material for a specific application during design

Based on the research analysis, the following conclusions were drawn:

1. the accuracy of the samples made depends on the thickness of the first layer, the number of scratches, calibration of the 3D printer, printing speed,

2. the best strength indexes were obtained with the honey-comb sample filling formula with a filling density of $80 \%$,

3. PET showed higher tensile strength values than MABS at different sample filling densities,

4. Strength properties decrease with increasing printing speed,

5. PET and MABS can be used as construction material in industry.

\section{References}

[1] Weiss Z., Konieczny R., Rojek M., Stępniak D., Projektowanie technologii maszyn w systemach CAD/CAM, Wydawnictwo Politechniki Poznańskiej, Poznań 1996.

[2] Siemiński P., Budzik G., Techniki Przyrostowe - Druk Drukarki 3D, Oficyna Wydawnicza Politechniki Warszawskiej, Warszawa 2015.

[3] https://cadxpert.pl/akademia-druku-3d/ [25.05.2021].

[4] Major M., Mindla I., Zastosowanie technologii druku przestrzennego w budownictwie, Zeszyty Naukowe Politechniki Częstochowskiej 2016, seria Budownictwo 22.

[5] Borysiewicz A., Gonera P., Łęgowik D., Dembiczak T., Gospodarek K., Wykorzystanie metody przyrostowej w prototypowaniu, Prace Naukowe Akademii im. Jana Długosza w Częstochowie, tom VI, 2018.

[6] PN-EN ISO 527-3:1998., Tworzywa sztuczne -- Oznaczanie właściwości mechanicznych przy statycznym rozciąganiu -- Warunki badań folii i płyt.

[7] Kęska P., SOLIDWORKS 2014 Modelowanie powierzchniowe, narzędzia do form, rendering i wizualizacje, Wydawnictwo CADVANTAGE, ISBN 978-83-936576-1-2.

\section{Analiza parametrów technologicznych druku 3D na właściwości wy- trzymałościowe gotowych wyrobów z MABS oraz PET}

\section{STRESZCZENIE:}

Celem pracy było poznanie wpływu parametrów technologicznych druku 3D w technologii FDM (Fused Deposition Modeling) na właściwości mechaniczne materiału MABS oraz PET. Próbki do badań statycznej próby na rozciąganie wydrukowano zgodnie z normą PN-EN ISO 527:1998. Tworzywa sztuczne. Oznaczenie właściwości mechanicznych przy statycznym rozciąganiu. Parametry wydruku dla każdej próbki bez względu na rodzaj użytego filamentu, były takie same. Zmianie jedynie ulegał parametr wypełnienia poprzez zmianę gęstości (20\%, 40\%, 80\%) oraz wzoru wypełnienia (wzór liniowy oraz honeycomb). Badania laboratoryjne przeprowadzono z wykorzystaniem uniwersalnej maszyny wytrzymałościowej. PET wykazał większe wartości wytrzymałości na rozciąganie od MABS przy różnych gęstościach wypełnienia próbki.

\section{SŁOWA KLUCZOWE:}

druk 3D; optymalizacja parametrów druku 3D; statyczna próba rozciagania; MABS; PET 